\title{
Three New Records of Genus Ptochus Schoenherr, 1826 (Coleoptera: Curculionidae: Entiminae) from Pakistan
}

\author{
Abdul Rauf Bhatti ${ }^{*}$, Ahmed Zia ${ }^{1}$, Falak Naz $^{2}$, Amjad Usman $^{3}$, Rukhshanda Saleem ${ }^{4}$, Ghulam Sarwar ${ }^{5}$ and \\ Amad Ud Din 6
}

${ }^{1}$ National Insect Museum, IPEP, NARC Islamabad, Pakistan; ${ }^{2}$ Department of Plant Protection, Karachi; ${ }^{3}$ Department of Entomology, The University of Agriculture, Peshawar, Khyber Pakhtunkhwa, Pakistan; ${ }^{4}$ Department of Zoology, University of Sialkot, Pakistan; ${ }^{5}$ Honey Bee Research Institute, NARC, Islamabad, Pakistan; ${ }^{6}$ Defense Housing Authority Islamabad, Pakistan.

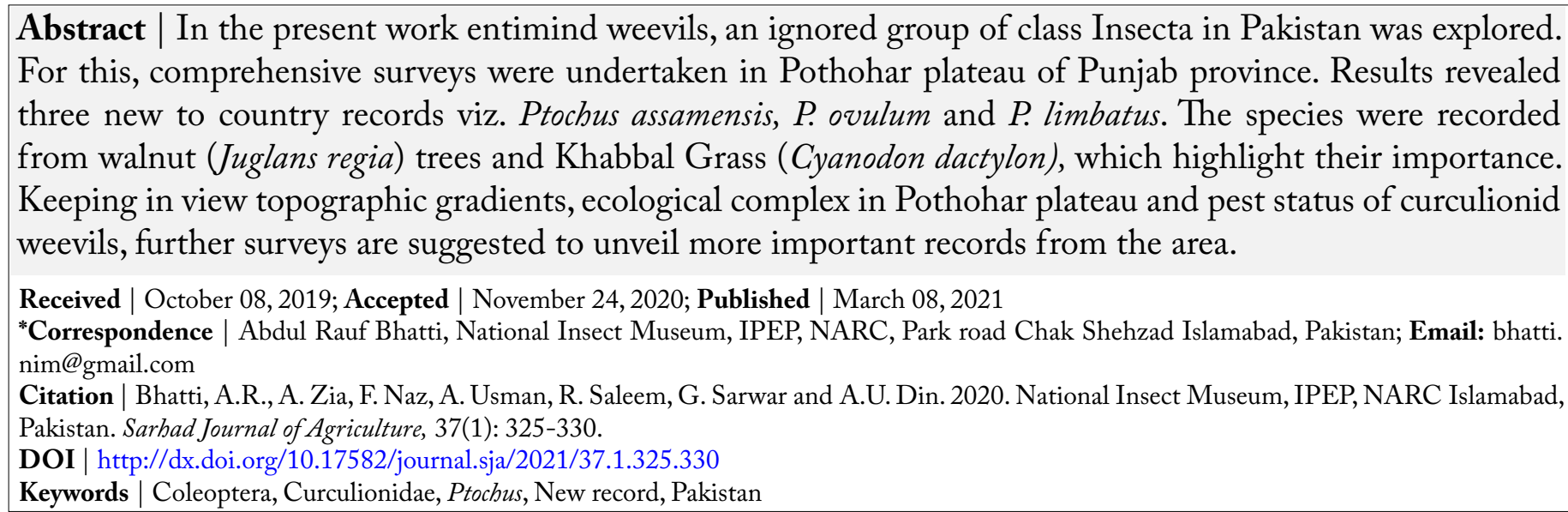

\section{Introduction}

W eevils belong to super family Curculionoidea of order Coleoptera (Zarazaga and Lyal, 1999). Most curculionids, are pests of fruits, seeds and leaves of crops and grains (Bhatti et al., 2018). Weevils attack almost each plant part and nearly every plant taxon (Anderson, 1995). Family Curculionidae (Zarazaga and Lyal, 1999) has a worldwide record of 62000 described species spread under 17 subfamilies (Bhatti et al., 2018) and 6000 genera (Tara et al., 2010; Marvaldi and Lanteri, 2005; Hammond, 1992; Spangler, 1982). Out of 17 subfamilies, Entiminae is broad nosed weevils distributed throughout the world particularly in the tropics with 55 tribes, 1340 genera (Nikolai et al., 2006) and 12,000 species (Zarazaga and Lyal, 1999). Many of these Entimines are important leaf feeders in their adult stage and root or shoot feeders in their larval stage. The genera namely Ptochus, Blosyrodes, Blosyrus, Cratopus, Cyrtozemia, Dermatoxenus, Drepanoderes, Geotragus, Lepidospyris, Leptomias, Pachynotus, Phacephorus and Atmetonychus are taxonomically important in India and the adjacent countries, especially Nepal, Bangladesh, Pakistan, Myanmar and Sri Lanka (Mahendiran, 2009).

Genus Ptochus is described by Schoenherr (1826) under broad group on which Gonatoceri and Marshall (1916) included under group Otiorrhynchides of the subfamily Otiorrhynchinae under the division Adelognathi. However, Thompson (1992) demoted Otiorrhynchinae to a tribe of Entiminae. Zarazaga and Lyal (1999) included under sub-tribe Myllocerina and tribe Cyphicerini of subfamily Entiminae. Ptochus was first described by Schoenherr (1826). It is well distributed in Oriental and European regions with 
79 species worldwide, Russia (twelve species), China (six species), Greece, Azerbaijan (five species each), Mongolia, Aremenia, Kazakhstan, Turkey, (three species each), Congo, Iran, Italy, Central Asia (two species each) and West Africa, Afghanistan, Croatia, Japan, Senegal, Kyrgyzstan and Serbia (one species each) are other regions (Mahendiran, 2009). Among neighboring countries to Pakistan, 22 species were recorded in India (Marshall, 1916), three species from Sri Lanka and one species each from Nepal and Myanmar (Mahendiran, 2009). However, four species under genus Ptochus are known to be recorded in Pakistan (Kazi et al., 2017). Being an agricultural country and in view of reported geographic range, Ptochus complex in Pakistan can easily be expected. In view of this, a comprehensive survey was conducted in various hilly localities in Potohar region to record weevil fauna.

\section{Materials and Methods}

Surveys were carried out during 2015-2017 to record adults of weevils in Himalayan foothills of Pakistan. Specimens were collected through hand picking, beating method and through sweep net from different localities of district Rawalpindi and district Islamabad. Ethyl acetate was used for killing collected specimens. Dead specimens were kept in separate vials. Information regarding locality, date of collection, and collector's name was written on vialusing lead pencil. Collected specimens were identified following Marshall (1916). For updated status of subfamily, Zarazaga and Lyal (1999) were followed and subfamily characterization had been taken through Thompson (1992). General morphological characters were examined using Olympus stereoscope, SZ2ILST.

Measurements of different body parts i.e., rostrum, elytra, antenna, legs, abdomen etc. were taken through divider and scale method. Coordinates and ecological data for the surveyed localities were recorded through GARMIN GPS and Metrological department respectively. GIS map for positive localities was developed using Arc GIS 10.5 software. Host plants were identified at National Herbarium Program (NHP) at National Agricultural Research Center (NARC) Islamabad. Identified specimens were kept at National Insect Museum for future reference and study.

\section{Results and Discussion}

Comprehensive surveys were undertaken during active season between 2015-2017 to explore adult weevils from Himalayan foothills of Pakistan which revealed three new records for Pakistan. A total of 40 specimens were recorded from two host plants (Walnut tree and Khabal grass) and four different localities of district Islamabad and Rawalpindi. Details for each recorded species are discussed below in Figures 1, 2 and 3.

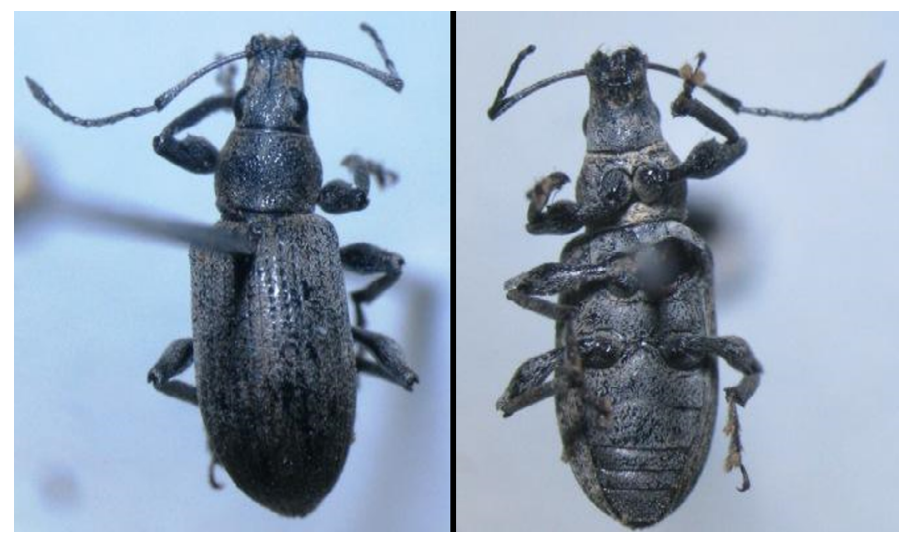

Figure 1: Dorsal view of Ptochus assamensis ventral view of Ptochus assamensis.

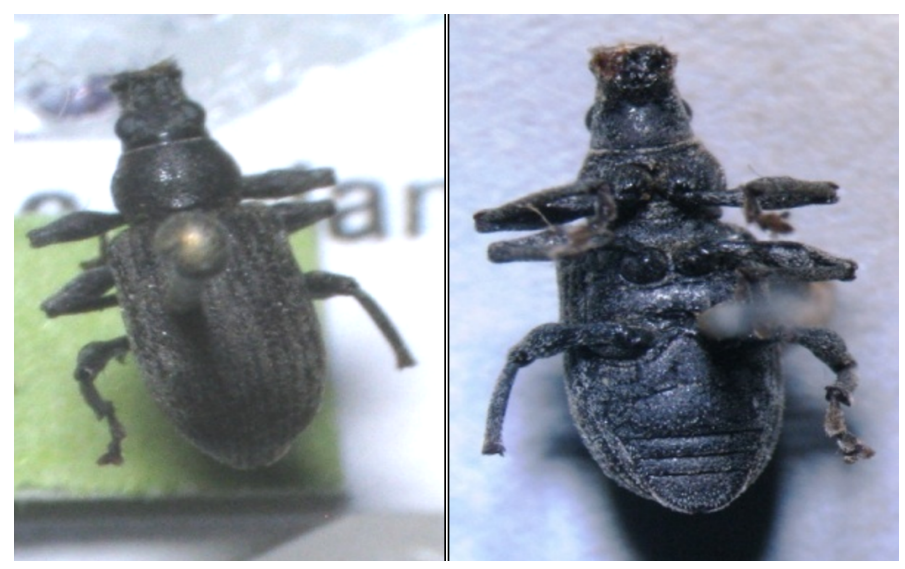

Figure 2: Dorsal view of Ptochus ovulum ventral view of Ptochus ovulum.

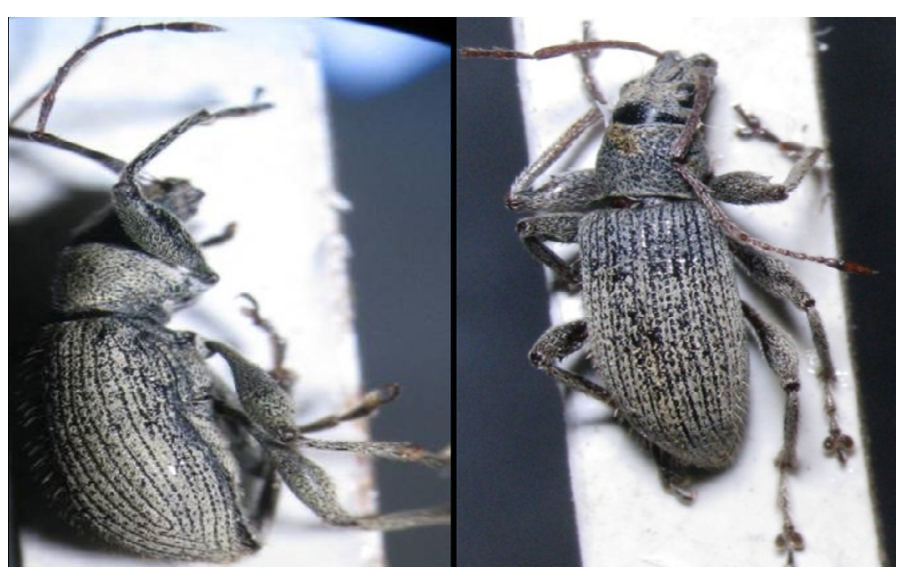

Figure 3: Lateral view of Ptochus limbatus dorsal view of Ptochus limbatus. 
Ptochus assamensis Marshall, 1916

Taxonomic description: Body black, with grey scales. Head wide; eyes located laterally, small, curved; forehead with impressed parallel stripes. Rostrum equally long and wide, apically dilated and stoutly conical from base to middle, upper surface shallowly impressed and tri-carinate with finely impressed parallel lines at base. Antennae pitchy black; funicle with basal two segments equal in length, segments 3-7 subequal and slightly longer than wide. Prothorax wider than long, sides markedly rounded, maximally broad medially with equal width at base and apex. Pronotum showing reduced central carina with irregular small rounded pits hidden by scales. Scutellum invisible. Elytra oval shaped, sub-truncate at base, maximally broad medially, with deeply punctate striae.

Body measurement: Length: 7.5-8 mm; Width: $2-2.5 \mathrm{~mm}$.

\section{Differential characters: Recorded specimen} resembled with published taxonomic description of Marshall (1916) except hind tibia having two claws which are free; Scape of antenna touches the prothorax margin and Venter with segment 1,2 equally in size and segment 2 also longer than $3+4$.

\section{Host plant: Walnut (Juglans regia) tree.}

\section{Earlier records for Pakistan: Nil.}

Remarks: This species has been recorded first time from country.

Distribution: India, South Asia (Marshall, 1916; Mahendiran, 2009).

\section{Ptochus ovulum Marshall, 1916}

Taxonomic description: General color black, with uniform pale scales at dorsum and ventrum. Head with impressed parallel line, central furrow visible at forehead, position of eyes sub-dorsal, nearly circular and moderately convex. Rostrum equally long and broad, sharply pointed from base to middle and dilated apically, upper surface elevated shallowly having visible carina showing small pits. Antennae dark ferruginous; funicle with joint 1 almost double in size of segment $2^{\text {nd }}$, basal joints 3-7 longer with elongate club. Prothorax oblong, sides particularly rounded, maximally broad at middle and equal width of apex and base together. Notum contains irregular small visible rounded. Scutellum visible. Elytra ovate, sub-truncate at base, broadest at middle and elytral interval consisting short depressed stiff hairs.

Body measurement: Length: $6.5-7 \mathrm{~mm}$; Width: $2-2.5 \mathrm{~mm}$

Differential characters: Recorded specimen tally with published taxonomic description of Marshall (1916) excludinghind tibia having two claws which are free and Venter with segment 1, 2 equally in size and segment 2 also longer than $3+4$.

Host plant: Khabbal Grass (Cynodon dactylon).

\section{Earlier records for Pakistan: Nil.}

Remarks: This species is recorded first time from Pakistan.

Distribution: India, South Asia (Marshall, 1916; Mahendiran, 2009).

\section{Ptochus limbatus Marshall, 1916}

Taxonomic description: Body reddish brown with dorsum having brown scales densely and ventrally located with uniform greenish-grey scales. Head having well defined lateral lines; eyes large and convex located sub-lateral. Rostrum oblong, step by step pointed from base to middle and apical side clearly dilated with three central carina along scrobes. Antennae ferruginous; funicle with joint $1^{\text {st }}$ longer than joint $2^{\text {nd }}$ and joints $3^{\text {rd }}$ while joint $4^{\text {th }}$ subequal and longer than rest with elongate club. Prothorax equally oblong, sides poorly rounded, wider medially. Scutellum distinct, clothed with green scales. Elytra with at ends equally narrow in male and wider in female, ending abruptly toward base, maximally broad at middle, striae contains small rounded deeply pits, fine striae appearance.

Body measurement: Length: 7.5-8 mm; Width: $2-2.5 \mathrm{~mm}$

Differential character: Recorded specimen has resemblance with published taxonomic description of Marshall (1916) and with these additional features i.e. Prothorax having long seta; funicle segment $3^{\text {rd }}$ slightly longer segment $4^{\text {th }}$ and segment $7^{\text {th }}$ also longer 
than segments $5^{\text {th }}$ and segment $6^{\text {th }}$ together.

Remarks: The taxonomic description of Marshall not provided any information regarding leg and ventral positioning. Following features, hind tibia having two claws which are free and venter with segment $1^{\text {st }}$ longer than segment $2^{\text {nd }}$ and segment $2^{\text {nd }}$ also longer than segment $3^{\text {rd }}$ and segment $4^{\text {th }}$ are additional.

Host plant: Walnut tree (Juglans regia).

\section{Earlier records for Pakistan: Nil,}

Remarks: This species is recorded first time from Pakistan

Distribution: From India, south Asia (Marshall, 1916).

Data for distribution of each recorded species and ecology of visited site is given in Table 1.

Details distribution for $P$ assamensis, $P$. ovulum and $P$. imbatus in Pothohar region of Pakistan are provided in Figure 4.

Present study was undertaken with an objective to explore weevil fauna of sub-Himalaya with special emphasis on genus Ptochus. Genus Ptochusis an important genus that includes species which acts as pests of a number of crops. This genus has a lot of economic importance which reveals that it is feeding not only on crops (Ding et al., 2000; Varma and Tandan, 1996; Zhou and Zhou, 1989; Butani and Jotwani, 1984; Nayar et al., 1976) but on plants as serious pest of roses, many greenhouse plants, as well as citrus and other fruit trees (Teriplehorn and Johnson, 2005). Radha et al. (1970) observed Ptochus ovulumas feeding on the medicinal plant Coleus aromaticus. This genus wasalso reported feeding on the Parthenium by
Kumar et al. (1979). Ptochus sp. was recorded as a pest of medicinal plant Gloriosasuperba from Bangalore (Hanumantha and Rajagopal, 1995a). In Pakistan, Kazi et al. (2017) reported four species under genus Ptochus (P. crinitus, $P$. noxius, $P$. percussus, and $P$. afficuts) which had been documented based on fauna of British India (Marshall, 1916). However, there is no information about host record. In present study, two out of three species, namely Ptochusasamensis and $P$. limbatus were recorded from walnut tree (Juglans regia) and one species namely $P$. ovulum feed on Khabbal grass (Cynodon dactylon) but its further systematic study in relation to host range should be carried out in future in theses area. If we investigate the universal distribution of these three species of genus Ptochus, these are Oriental species documented from India and South Asia (Marshall, 1916). With the inclusion of three Ptochus species through present work, total number of reported species under genus Ptochus reaches to seven.

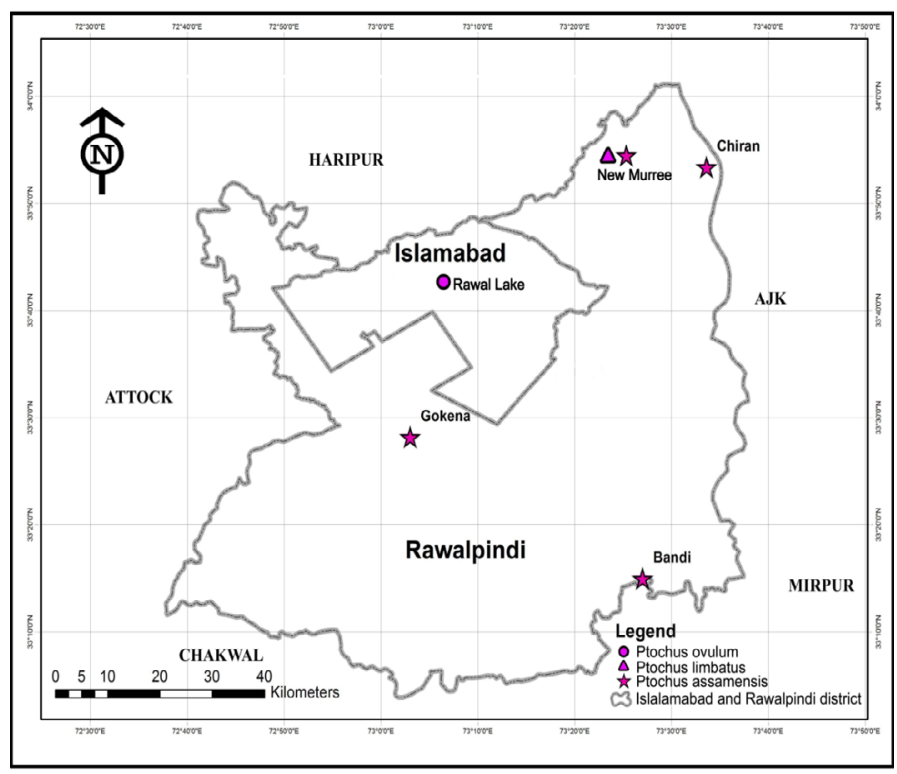

Figure 4: Distribution for $P$ assamensis, $P$. ovulum and $P$. imbatus in Potohar region of Pakistan.

Table 1: Distribution and ecological observations for P. assamensis, P. ovulum and P. limbatus.

Material examined

\begin{tabular}{|c|c|c|c|c|c|c|c|c|c|c|}
\hline Species & Province & District & Locality & $\hat{0}$ & q & Date & Lat. (N) & Long.'(E) & Height (Ft) & Temp. $\left({ }^{\circ} \mathrm{C}\right)$ \\
\hline \multirow{4}{*}{$\begin{array}{l}\text { Ptochus } \\
\text { assamensis }\end{array}$} & \multirow[t]{4}{*}{ Punjab } & Islamabad & Gokina & 1 & - & 26-viii-2016 & $33^{\circ} 47$ & $73^{\circ} 05$ & 3259 & 28 \\
\hline & & \multirow[t]{3}{*}{ Rawalpindi } & New Murree & 5 & 2 & $17-v-2016$ & $33^{\circ} 54$ & $73^{\circ} 23$ & 7587 & 29 \\
\hline & & & Chirah & 3 & 3 & $17-v-2016$ & $33^{\circ} 25$ & $73^{\circ} 45$ & 2254 & 29 \\
\hline & & & Baandi & 4 & 2 & $17-v-2016$ & $33^{\circ} 25$ & $73^{\circ} 45$ & 2254 & 29 \\
\hline Ptochus ovulum & Punjab & Islamabad & Rawal Lake & 1 & - & 18-vii-2016 & $33^{\circ} 70$ & $73^{\circ} 12$ & 1765 & 32 \\
\hline Ptochus limbatus & Punjab & Rawalpindi & New Murree & 11 & 09 & $17-v-2016$ & $33^{\circ} 90$ & $73^{\circ} 39$ & 7587 & 29 \\
\hline
\end{tabular}

\section{Coordinates Ecological paramaters}

Lat. (N) Long.'(E) Height $(\mathrm{Ft})$ Temp. $\left({ }^{\circ} \mathrm{C}\right)$

March 2021 | Volume 37 | Issue 1 | Page 328 


\section{Conclusions and Recommendations}

Keeping in view the findings of present work, it can easily be concluded that Pothohar plateau of Punjab province has a rich curculionid fauna which need to be further explored in perspective of topographic gradients and ecological complex represented by the plateau.

Keeping in view findings of present study and economic importance of weevils, Curculionid fauna should be explored in details from each ecological zone of the country.

\section{Novelty Statement}

These three species are first time reported from Pakistan known as New records from genus Ptochus of the Pakistan.

\section{Author's Contribution}

Abdul Rauf Bhatti: Collection of field data and designed the experiments.

Ahmed Zia: Facilitated in editing of tables regarding ecological data and GIS Map.

Falak Naz: Assisted in paper writing and proof reading.

Amjad Usman: Facilitated in the taxonomic part at confirmation of species.

Ghulam Sarwar: Assisted in paper writing (Introduction and justification of study).

Rukhshanda Saleem: Assisted in paper writing and proof reading.

Amadud Din: Facilitated in collection of field data.

\section{Conflict of interest}

The authors have declared no conflict of interest.

\section{References}

Anderson, R.S. 1995. An evolutionary perspective on diversity in Curculionoidea. Memoirs Entomol. Soc. Washington, 14: 103-114.

Bhatti, A.R., 2018. Weevil (Coleoptera: Curculionidae) fauna of Himalayan foot hills of Pakistan. M. Phil. thesis, Dept. Plant Environ. Prot. PIASA, Univ. Agric. Peshawar, Pakistan, pp. 137.

Bhatti, A.R., A. Zia, M.I. Mastoi, M. Ilyas A. Shehzad and J.Iqbal. 2018. Tanymecusxanthurus
Chevrolat, 1880 (Curculionidae: Entiminae), a new addition to Curculionid fauna of Pakistan. Pak. Entomol., 40(2): 91-94.

Butani, D.K. and M.G. Jotwani. 1984. Insects in vegetables. Periodical export book agency, India, pp. 343.

Chao, Y. and Y. Chen. 1980. Chinese Leptomias Faust and its allied genera in the Qinghai-Xizang plateau district (Coleoptera: Curculionidae). Entomotaxonomia, 2(2): 85-107.

Ding,J., Q.Zhang,J.Xu, G.Wang, Z.Ma, B.Li and J. Lu. 2000. Infestation of Phytoscaphusgossypii Chao and its control in cotton growing areas of southern Hebei. Plant Prot., 26(3): 17-19.

Hammond, P.M., 1992. Species inventory. pp. 17-39. In: Groombridge B. (Ed.). Global biodiversity status of the earth's living resources. Chapman and Hall. London. pp. 246. https:// doi.org/10.1007/978-94-011-2282-5_4

Hanumantha, S.B.C. and D. Rajagopal. 1995a. Insect pests of Gloriosa superb Linn. Indian medicinal plant. Indian J. For., 18(2): 158-160.

Ismailova, M.S., 2006. A review of the weevil genus Ptochus Schoenh. (Coleoptera: Curculionidae) of the fauna of Daghestan. Entomol. Rev., 86(9): 1002-1015. https://doi.org/10.1134/ S0013873806090041

Kazi, A.J., I. Khatri, M.A. Rustamani, W.A. Panhwar, R. Sultana and A. Ahmed. 2017. Records of family CurculionidaeLatreille, 1802 (Coleoptera: Insecta) in Fauna of British India segregated for boundaries of Pakistan. Biologia, 63(1): 1-3.

Kumar, S., S. Jeyaraj and T.S. Muthukrishnan. 1979. Natural enemies of Partheniumbysterophorus Linn. J. Entomol. Res., 3(1): 32-35.

Lacordaire, T., 1863. Histolre Naturelle des Insectes. Genera des Coleoptresouexposemethodiqueet critique de tous les genres proposes jusqu 'ici dons cetordred' insectes. 6: 637.

Linnaeus, C., 1758. Systema naturae per regna trianaturae, secundumclasses,ordines, genera, species, cum caracteribus, differentiis, synonymis, 10(1): 824.https://doi.org/10.5962/ bhl.title. 542

Mahendiran, G., 2009. Taxonomic studies on some short snout entimine weevils of India and adjacent countries. Ph. D. thesis, Div. Entomol. Indian Agric, Res, Inst. New Delhi-110012, India.

Marshall,G.A.K.,1916.Coleoptera.Rhynchophora: 
Curculionidae. In: Shipley, A.E. (ed.): The Fauna of British India, including Ceylon and Burma. London. Taylor and Francis, pp. 367.

Marvaldi, A.E. and A.A. Lanteri. 2005. Key to higher taxa of South American weevils based on adult characters (Coleoptera, Curculionoidea). Rev. Chilena Hist. Natl., 78: 65-87. https://doi. org/10.4067/S0716-078X2005000100006

Nayar, K.K., Ananthakrishnan and B.V. David. 1976. General and applied entomology. Tata Mcgraw Hill, India, pp. 573.

Nikolai, N.Y. and S.N. Konstantin. 2006. New taxa of geophilic entiminae (Coleoptera: Curculionidae) from the Balkan Peninsula, Caucasus, and central Asia. Entomologische Abhandlungen, 63(1-2): 77-98.

Radha, N.V.,P.V.Subba Rao, R. Sivagami and P.V.S. Rao. 1970. Some pests of Coleus aromaticus Benth. Indian J. Entomol., 32(1): 92-94.

Schoenherr, C. J. 1826. Curculionidum dispositio methodica cum generum characteribus descriptionibus atque observationibus variis seu Prodromus ad Synonymiae Insectorum, partem IV, Lipsiae. Fleischer. X+338 pp.

Spangler P.J., 1982. Introduction to the 1982 Edition. In: Blackwelder R.E. Checklist of the Coleopterous Insects of Mexico, Central America, the West Indies, and South America. Smithsonian Institution, United States Nat. Mus. Bull., Vol. 185. parts 1-6.

Supare, R.N., S. Ghai and V.V. Rammurthy. 1999. A revision of Tanymecusfrom India and adjacent countries (Coleoptera: Curculionidae). Oriental
Insect., 24: 1-126. https://doi.org/10.1080/003 05316.1990 .11835533

Talwar, N., 2014. Trophic relationships, Life cycle strategies and distribution pattern of genus Curculio (Curculioninae: Curculionidae: Coleoptera), Indian J. For., 36: 463-466.

Tara, J.S., S. Sunail and K. Ramnik. 2010. A record of weevil (Coleoptera: Curculionidae) diversity from district Samba ( $\mathrm{J}$ and $\mathrm{K}$ ). The Bioscan, 5(3): 391-394.

Teriplehorn, C.A. and N.F. Johnson. 2005. Borror and DeLong's introduction to the study of insect. Thomson. Publ ( $7^{\text {th }}$ Edit). 864. pp. 459.

Thompson, R.T., 1992. Observations on the morphology and classification of weevils (Coleoptera, Curculionidae) with a key to major groups. J. Natl. Hist., 26: 835-891. https://doi. org/10.1080/00222939200770511

Varma, A. and B.K. Tandan. 1996. Pathogenicity of three entomogenous fungi against insect pests of sugarcane. J. Biol. Contr., 10(1/2): 87-91.

Zarazaga, M.A.A. and C.H.C. Lyal. 1999. A world catalogue of families and generas of Curculonodea (Insect: Coleoptera). The natural History Museum. Entomipaxis, C.P. Edtion.

Zhou, W.N. and Y.C. Zhou. 1989. Investigation on species of weevils on mulberry in Sichuan. Acta Sericol. Sin., 15(2): 71-73.

Zia, A., 2010. Biosystematics of damselflies (Zygoptera: Odonata) of Pakistan. Ph. D. thesis, Dept. Agric. Entomol., PMAS Arid Agric, Univ., Rawalpindi, Pakistan. 